$<$ 綜 説 $>$

（受理 : 平成 16 年 6 月 29 日）

\title{
熱溶融エポキシ樹脂とその応用 \\ The Novel Reversible Epoxy Resin and FRTP Made of It
}

\author{
西口隆公 \\ Takahiro NISHIGUCHI
}

\section{1.はじめに}

昨今では，様々な用途でリサイクルへの対応が進んで いる。環境アセスメントの错点からみると，熱硬化性の ポリマーは 3 次元架橋することにより, 高強度を発現す るため, 製品の分別回収を行うには，分別回収が非常に やっかいなポリマーと言える。特に接着性と耐熱性を特 長とするエポキシ樹脂は，もっとも分別しづらいポリマー といえる。

高強度とリサイクルが両立できる，新たな機能をもっ たエポキシ樹脂ができれば，エポキシ樹脂もその特長を 生かしながら、リサイクルを前提とした新しい製品の用 途への適用が期待できる。本報では, リサイクルのため に我々が考えたエポキシ樹脂の熱溶融機能の出現手法と, FRP 成型品に応用した場合を例にとり，熱溶融エポキ シの特長を紹介する。

\section{2. エポキシ樹脂の熱溶融化}

従来の熱硬化性樹脂は, 初期状態において低分子（モ ノマーないしはオリゴマー）から成る組成物であるため 低粘度であり，無溶剤で染布性に優れている。それが加 熱等の硬化条件に曝された時，各分子間に化学結合のラ ンダムな形成が起こり,ゲル化を経て最終的には密な架 橋構造（ネットワーク）を形成して完全な硬化物となる。 この硬化物は，主鎖の分子運動が凍結されているガラス 状態から，主鎖の周りにミクロブラウン運動しているコ ム状態に転移する，いわゆるガラス転移温度を有してい るものの，それ以上温度を上げても決して溶融状態にな ることはなく，また溶剤に溶解することもない，不溶不

*ナガセケムテックス株式会社: 電子・構造材料事業部 兵庫県竜野市竜野町中井 236 于 $679-4124$

Nagase Chemtex Corporation

236, Tatsunocho-nakai, Tatsuno, Hyogo, Japan 679-4124
融の三次元架橋体であるのが特徴である。

それに対して, 新規に開発した熱溶融エポキシ樹脂は, 初期状態においては低分子から成る低粘度組成物であり, この状態では従来の熱硬化性樹脂と同様の特性を備えて いる。ところが, 加熱硬化の条件に曝されると, 各分子 の官能基が 1 対 1 の付加反応をし，その結果として直鎖 状ポリマーに生長するが決して架橋構造をとることがな い。硬化反応が終了した熱溶融エポキシ樹脂は, 熱可塑 性樹脂と同様の挙動を示し，その熱的寸法安定性は架橋 密度ではなく, 専ら主鎖の化学構造的な剛直性に依存し ている。このような構造に起因して, 硬化後も再度加熱 することにより, 再溶融させることが可能である。

\section{1 エポキシ樹脂の熱溶融化機構}

上述のエポキシ樹脂の熱溶融化機構を, エポキシ樹脂 とフェノール系の硬化剤との反応について示す。2 官能 性のエポキシとフェノールの反応は式1で示したような 機構で直鎖状に反応が進むことが熱溶融性を発現する為 の必須条件である。そこで, 我々は表 1 に示した各種触 媒を用いた反応について検討を進めた。反応触媒を用い たエポキシとフェノールの反応は式 2 に示すような (a),

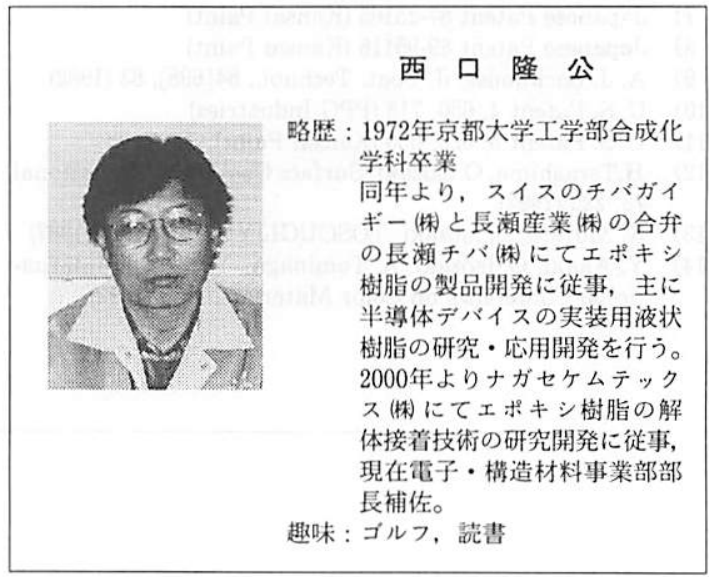


(b), (c) の 3 種類の反応が考えられる。(a) 反応はエポ キシの自己重合反応であり，（b) 反応は (c) 反応で生じ る 2 級アルコール性 $\mathrm{OH}$ 基又はエポキシの自己重合反 応で生じる 2 級アルコール性 $\mathrm{OH}$ 基との反応である。
又, (c) 反応はフェノール樹脂の $\mathrm{OH}$ 基との反応である。 表 1 には $5{ }^{\circ} \mathrm{C}$ から $210^{\circ} \mathrm{C}$ まて昇温される間に 2 官能ビ スフェノールA 型エポキシ骨格中に含まれる 2 級 $\mathrm{OH}$ 基と反応触媒のみとの反応熱を示した。これから分かる

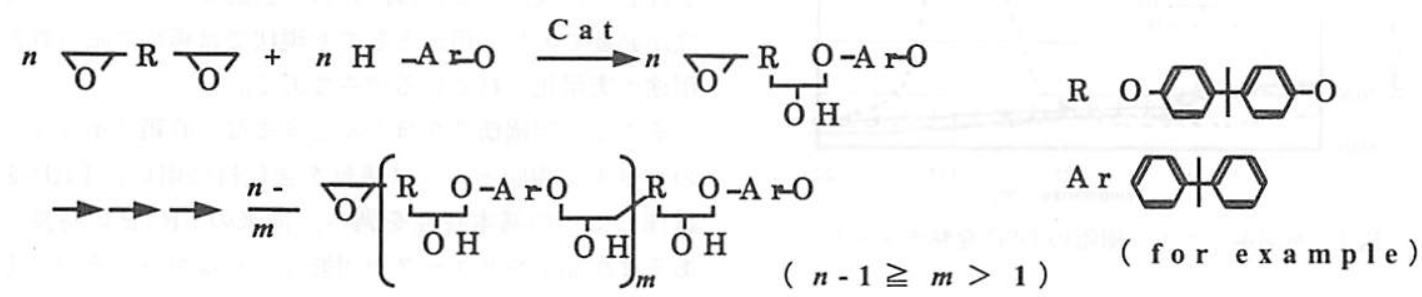

式 1 エポキシ樹脂の熱溶融化反応機構

表 1 各種触媒によるエポキシ樹脂の反応熱

\begin{tabular}{|c|c|c|}
\hline Catalyst & 略称 & $\begin{array}{c}\mathrm{a} \Delta \mathrm{H}_{1}+\mathrm{b} \Delta \\
\mathrm{H}_{2} \\
(\mathrm{~J} / \mathrm{mg})\end{array}$ \\
\hline 2-Phenyl imidazole & $2 \mathrm{PZ}$ & 57.2 \\
\hline Triphenyl phosphine & TPP & 3.3 \\
\hline Tri-o-tolyl phosphine & TOTP & 0.0 \\
\hline Tri-p-tolyl phosphine & TPTP & 5.7 \\
\hline Dicyclohexylphenyl phosphine & DCPP & $4.2^{* * *}$ \\
\hline Triphenyl phosphin triphenyl boron & TPPS & 1.5 \\
\hline $\begin{array}{l}\text { Tetraphenyl phosphonium } \\
\text { tetraphenyl borate }\end{array}$ & TPPK & 26.2 \\
\hline Tetraphenyl phosphonium bromide & TPPPB & $0.0^{* * *}$ \\
\hline Tetramethyl ammonium chloride & TMAC & $0.0^{* * *}$ \\
\hline N-benzyl DBU** tetraphenylborate & DBUK & $0.0^{* * *}$ \\
\hline $\begin{array}{l}\text { 3-(3,4-Dichlorophenyl)-1,1- } \\
\text { dimethylurea }\end{array}$ & DCMU & 6.7 \\
\hline
\end{tabular}

* 触媒添加量: $1 \mathrm{phr}$

** DBU: 1,8-Diazabicyclo $(5,4,0)$ undecene-7

***更なる昇温で発熱発現
ように反応触媒の中で. 2 -フェニルイミダゾール (2PZ) 及びテトラフェニルフォスホニウムーテトラフェニルボ レート (TPP-K) は非常に大きい発熱を示している, これはこれら反応触媒が (a) 反応によるエポキシ基 との反応性が高いことを示している。一方, 反応触媒の 内トリオルソトリルフォスフィン (TOTP), テトラフェ ニルフォスホニウムーブロマイド (TPP-PB), テトラ メチルアンモニウムクロライド (TMAC) 及びN-ベン ジル DBU テトラフェニルボレート $(\mathrm{DBU}-\mathrm{K})$ ではこ の発熱が見られていない。しかしながら, TOTP を除 いた反応触媒では $200^{\circ} \mathrm{C}$ 以上の温度条件で発熱が認めら れる。そこで, 以降の反応解析に用いる反応触媒として は, エポキシ樹脂の自己重合を起こし難い TOTP を用 いて検討を進める。

ピスフェノールA 型エポキシ/ビスフェノール F/ TOTP 系の $150^{\circ} \mathrm{C}$ 硬化の条件にて様々な評価を行なった 結果を以下に示す。

(a)

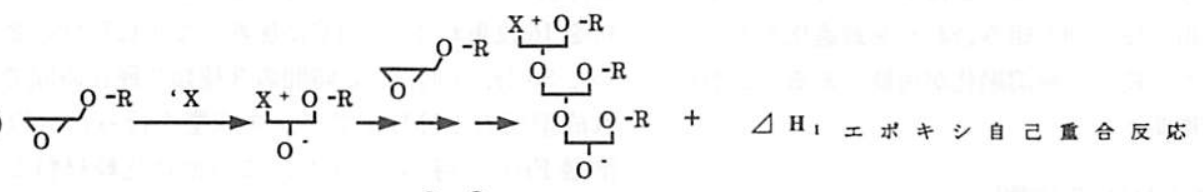

(b)

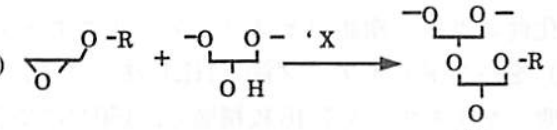

$+\triangle \mathrm{H}_{2} 2$ 唚アルコールOH 基付加反必

(c)<smiles>[R2][C+][NH2+]OC1CO1</smiles><smiles>[R]OC(O)COc1ccc([R4])cc1</smiles>

$+\Delta \mathrm{H}_{3} \mathrm{~T}=$ 人 $-\mathrm{N} \mathrm{OH}$ 基付加反灾

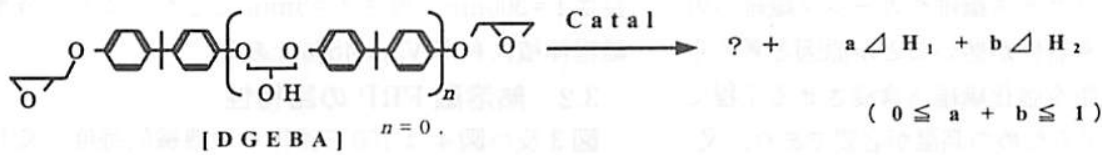

式 2 エポキシ樹脂の反応機構 


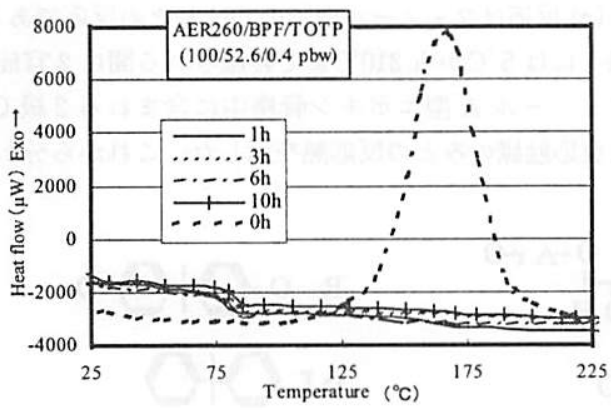

図 1 熱溶融エポキシ樹脂の DSC 発熱チャート

\begin{tabular}{cccc}
\hline $\begin{array}{c}\text { 重合化 At } \\
150^{\circ} \mathrm{C}(\mathrm{h})\end{array}$ & $\mathrm{Mw}$ & $\mathrm{Mn}$ & $\mathrm{Mw} / \mathrm{Mn}^{*}$ \\
\hline 1 & 22506 & 10568 & 2.1 \\
3 & 48716 & 15506 & 3.1 \\
5 & 71812 & 17961 & 4.0 \\
7 & 86755 & 19003 & 4.6 \\
10 & 96663 & 19601 & 4.9 \\
\hline
\end{tabular}

* means polydispersity

高圧力が必要となる。このため, 熱可塑性樹脂をマトリッ クスとする FRTP は，2 次加工性やリサイクル，リユー ス性に優れるといった特徵をむってはいるものの, 成形 時に非常に高いエネルギーが必要となり, 大型の成形品 を経済的に成形するには，材料・装置等のシステムの確 立が必要であり，用途としてあ現状では極めて限られた 用途へ実用化されているのみである。

そこで，架橋構造をほとんど含まない直鎖状ポリマー のエポキシ樹脂とガラス瀻維を強化材に用いた FRP を 試作してその基本特性を調へ，従来の FRTP の特長で ある 2 次加工やリユースが可能でありながら，その一方

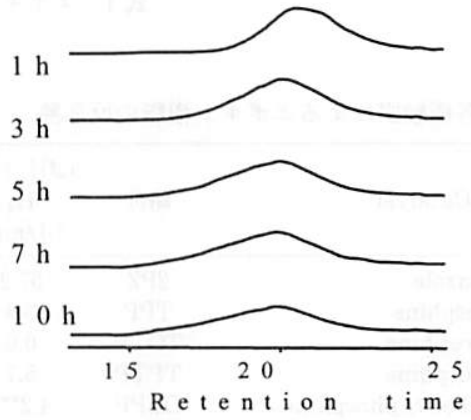

図 2 熱溶融エポキシ樹脂の GPC 变化

図 1 の DSC グラフから, $150^{\circ} \mathrm{C}$ 硬化温度では, 1 時 間で反応がほとんど終了しており, $\mathrm{Tg}$ も $80^{\circ} \mathrm{C}$ 近辺で安 定しており， 1 時間以上加熱しても $\mathrm{Tg}$ の変化はほとん ど認められない。しかしながら, 図 2 の GPC では重合 の数平均分子量が 10,000 から 20,000 まで硬化時間に応 じて増加の傾向を示している。これらの結果は, 本系の 反応機構が，ビニル基の重合の様な連鎖反応ではなく， 逐次反応により進行していることによると考えられる。

エポキシ樹脂と硬化剂の組み合わせを最適化すること により, エポキシ樹脂の熱溶融化が可能であることが以 上の結果より推測される。

\section{3. 熱溶融 FRP の作製}

現在, 実用化されている長織維で強化した熱可塑性樹 脂をマトリックスとする FRTP は, カーボン繊維とポ リエーテルェーテルケトン（PEEK）との ACM な゙そ の種類は極めて少ない，その原因としては，複合材料と して熱可塑コンポジットは力学的な特性が得られ難いこ とが上げられる。これはガラス織維やカーボン織維への 熱可塑性樹脂の接着・密着性が悪いことが原因と考えら れる。又, 熱可塑性樹脂を強化織維へ含浸させる工程で は, 熱可塑樹脂を溶融するための高温が必要であり, 又, 高溶融粘度の熱可塑樹脂を強化䋐維へ含浸させるための
では, 熱硬化性樹脂をマトリックスとする FRP と同等 の成形性を有する FRP の開発を試みた。

\subsection{FRP の試作}

ドライの状態のガラスクロス（WEA1901: 日東紡績 (琍) に，溶剤（メチルセロソルブ）を重量部数で $20 \%$ 混入した熱溶融エポキシ樹脂（IF-31，ナガセケムテッ

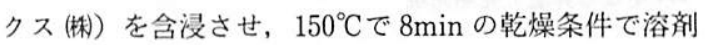
を除去してプリプレグ基材に加工した。このプリプレグ 材を 16 枚重ねて, $150^{\circ} \mathrm{C}$ に加熱した平板形状の金型を用 いて 30 分, 1 時間, 3 時間の 3 種類の硬化時間でそれぞ れ成型圧力 $1.0 \mathrm{MPa}$ でプレス成型を行った（以下，熱 溶融 FRP と呼ぶ)。また, この他に比較材料として, 熱硬化性エポキシ樹脂（ビスフェノールエポキシ/酸無 水物）をハンドレイアップ法（HLU法）にて,ドライ の状態のガラスクロスを 16 枚積層し, $150^{\circ} \mathrm{C} に て 3$ 時間, 成形圧力 $1.0 \mathrm{MPa}$ でプレス成型を行った（以下，熱硬 化 FRP と呼ぶ)。FRP 積層板の仕上がり寸法は, どち らの板む同じ寸法になるように調整し，幅 $\mathrm{b}=300 \mathrm{~mm}$, 長さ $\mathrm{l}=300 \mathrm{~mm}$, 厚さ $\mathrm{t}=3 \mathrm{~mm}$ とした。また, 成形品の 織維体積含有率 $\mathrm{V}_{\mathrm{f}}$ は $45 \%$ である。

\section{2 熱溶融 FRP の諸特性}

図 3 及び図 4 は $150^{\circ} \mathrm{C}$ 硬化での機械的強度の変化を示 す。図 3 の曲げ強度, 図 4 の引張せん断強度はそれぞれ, 


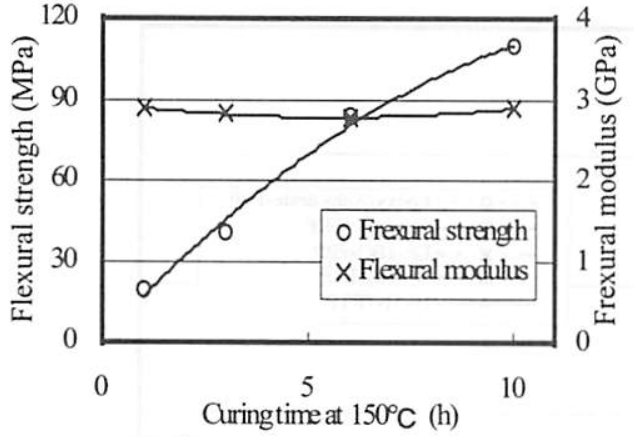

図 3 硬化時間と曲げ特性の関係

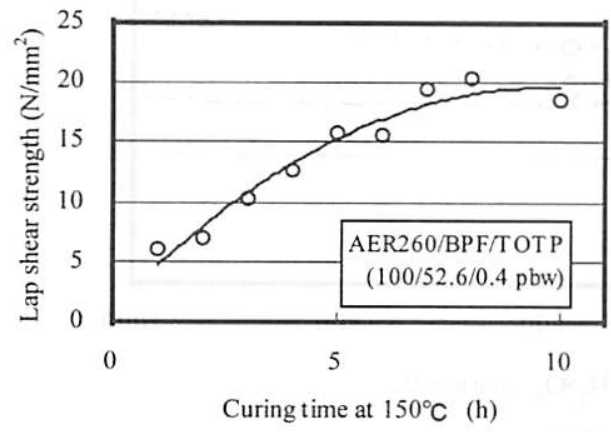

図 4 硬化時間と接着強度の関係

硬化時間の延長による強度アップが認められる。GPC での分子量増加及び機械的強度アップの結果より, 強度 発現のためには, 今回の熱溶融エポキシは逐次反応であ るため, 一定以上の分子量がを得るための時間が必要で あり, 又, 図 1 及び図 3 のデーターからは, 弾性率や $\mathrm{T}_{\mathrm{g}}$ は, 樹脂骨格の剛直度に関係し, 分子量の增加によ る変動はほとんどないと考えられる。更に, 今回の重合 物は, 3 次元架橋構造を有さないにもかかわらず, 高い 接着力を示すことより, ある程度の芳香環と水酸基を有 することが接着性への効果があることが確認された。

$150^{\circ} \mathrm{C} / 60 \mathrm{~min}$ の成形条件で試作した熱溶融 FRP の 動的粘弾性試験の結果を図 5 に示す。図 5 から明らかな

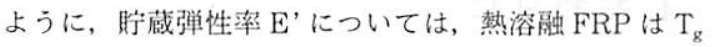
以上の温度域で, 熱硬化 FRP と比較すると貯蔵弾性率 の大きな低下を示す。一方, 損失の温度分散結果からは, 熱硬化 FRP は, $\mathrm{T}_{\mathrm{g}}$ 点に差し掛かると $\tan \delta$ が急激に増 大し, 転移を終了すると元の低い值に復帰することが確 認できる。これに対し, 熱溶融 FRPの場合, $T_{g}$ 点に差 し掛かると $\tan \delta$ が急激に増大するが，それ以上高温に なっても元の $\tan \delta$ 値に復㷌することなく高い値を維持 している。これは, 熱溶融FRP がマトリックスの $\mathrm{T}_{\mathrm{g}}$ 以上で粘性的性質が大きくなり, 溶融（再液状化）して いることを示唆している。

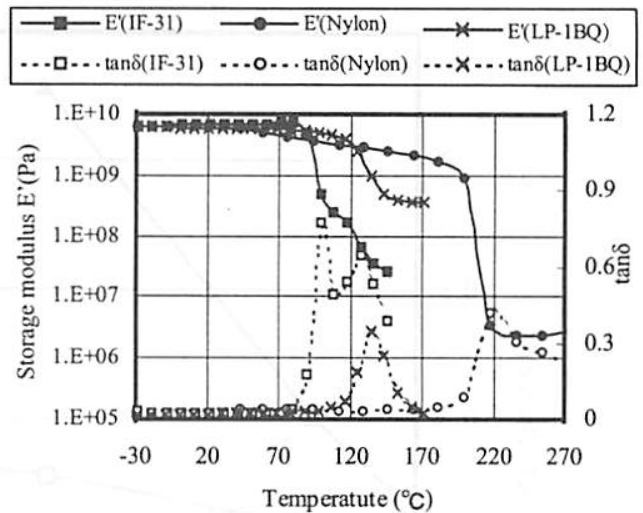

図 5 各種 FRP の粘弾性特性

又, 試作した熱溶融FRP の 2 次加工性を確認するた め, 高さ $\mathrm{h}=3 \mathrm{~mm}$, 幅 $\mathrm{b}=50 \mathrm{~mm}$, 長さ $\mathrm{L}=250 \mathrm{~mm}$ の試 験片を $160^{\circ} \mathrm{C}$ に加熱し, 山高さ $\mathrm{H}=48 \mathrm{~mm}$, ピッチ $\mathrm{P}=$ $146 \mathrm{~mm}$ の FRP 製の波板で挟み込んで曲げ加工を行っ た。この際, 波板には鉛直方向に $50 \mathrm{~N}$ の荷重を作用さ せた。その結果を写真 1 に示す。
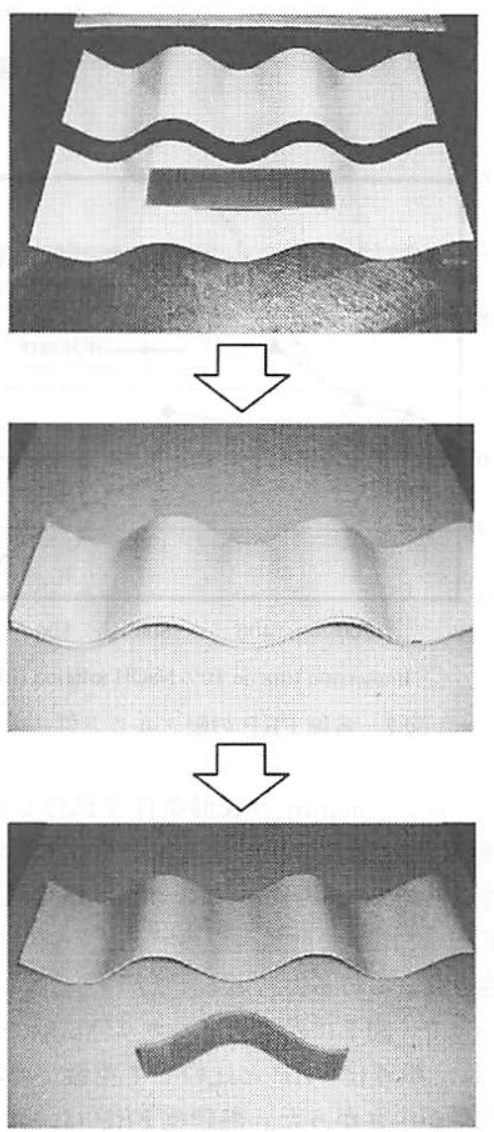

写真 1 熱溶融 FRP の 2 次加工性 


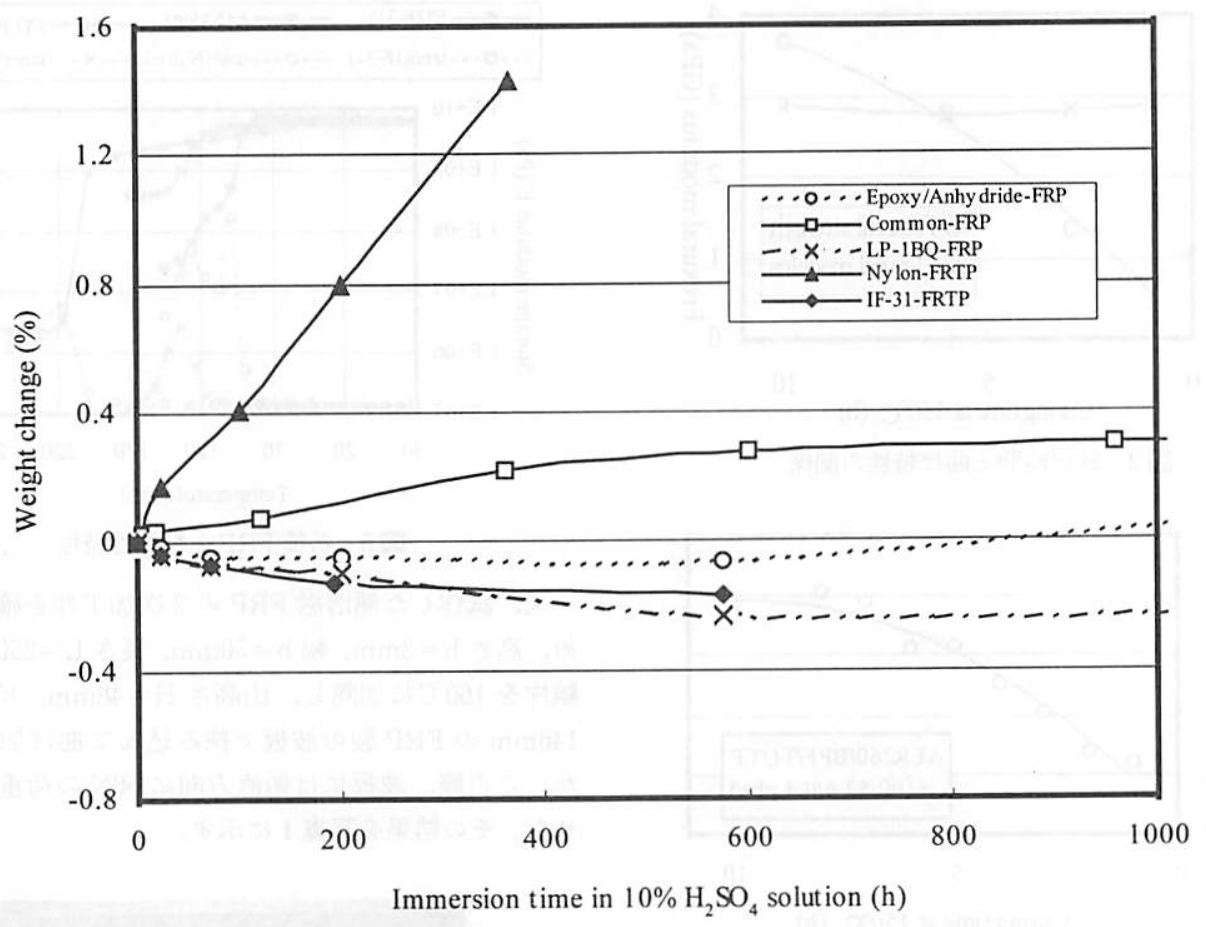

図 6 各種FRP の耐酸性

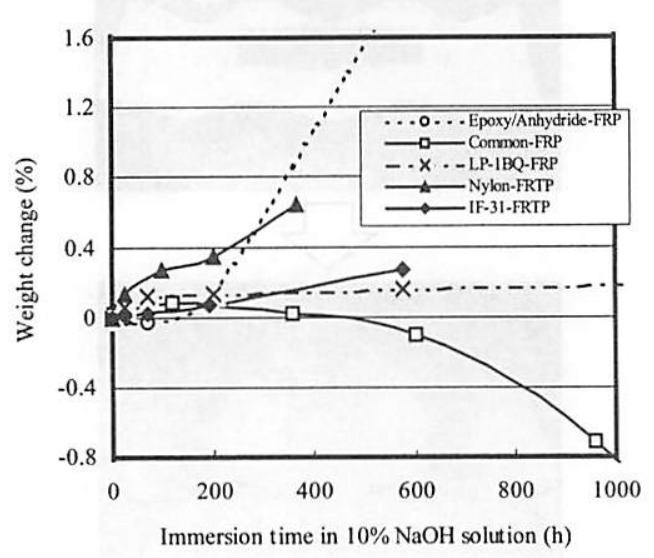

図 7 各種 FRP の耐アルカリ性

次に, $150^{\circ} \mathrm{C} / 60 \mathrm{~min}$ の成形条件で試作した熱溶融 FRP の耐薬品試験の結果を図 6 及び図 7 に示す。図 6 の耐酸性試験結果から明らかなように, 熱溶融FRP は, 熱硬化 FRP に比べて重量, 厚み寸法ともに，ほぼ同等 の耐酸性を有していると言える。

その一方で, 図 7 に示す耐アルカリ性試験では, 熱溶 融 FRP は, 熱硬化 FRP と比較して重量, 厚み寸法と あに变化量が小さかった。熱硬化 FRP は, マトリック スが酸無水物硬化型エポキシ樹脂からなり，骨格中にエ
ステル結合を多く有している。このエステル結合がアル カリ条件下により加水分解を起こしたため, 重量, 厚み 寸法変化量が大きくなったと考えられる。それに対して 熱溶融 FRP は, フェノール硬化型エポキシ樹脂で骨格 中にエステル結合を有さないため, 加水分解が起こり難 いと考えられる。

これらの結果より, 熱溶融FRPは, 耐酸性について は熱硬化 FRP と同等の耐性を有する一方で, 耐アルカ リ性においては, 熱硬化 FRP よりも優れた耐食性を示 しており, 耐薬品性についても熱硬化 FRP と同等以上 の性能を示す。

\section{4. おわりに}

今回の実験により, 従来の熱硬化性樹脂と同様の成型 条件にて, 熱可塑性の性能を持つ FRP 成型品の作製が 可能であることが確認された。又, この新規の熱可塑性 FRP は従来の熱硬化 FRP 成型品之同等の機械的強度を 持ちながら, 特定の温度にて容易に 2 次加工ができる特 長を持っている。この特長をさらに生かすため, HLU 法以外の成型法への適用, 2 次加工性の温度の調整等が 実用上必要と考えられるが, 熱溶融 FRP 成型品の実用 化は目の前にせまってきている。

又, 熱溶融機能を生かした接着剤システムについても, 
今回の実験之同様に高強度化の研究を進めておりリサイ クルの新素材として, 様々な用途への適用検討が進めら れており，その実用化が期待される。

\section{文献}

1）西口隆公，日本機械学会，機械材料・材料加工部門企画 No. 01-86 講習会「リサイクルの必須アイテム，解体接着 技術の原理と応用」30.11.2001

2）西田裕文他，第 41 回日本接着学会「熱溶融エポキシ樹脂 とその応用」 27.6 .2003

3）西田裕文他，日仏メカトロニクス会議「The novel reversible epoxy resin and FRTP made of it」10.9.2003

4）平山紀夫他，第 48 回 FRP CON-EX 2003「熱溶融エポ キシ樹脂を使用した FRP の開発」29.10.2003

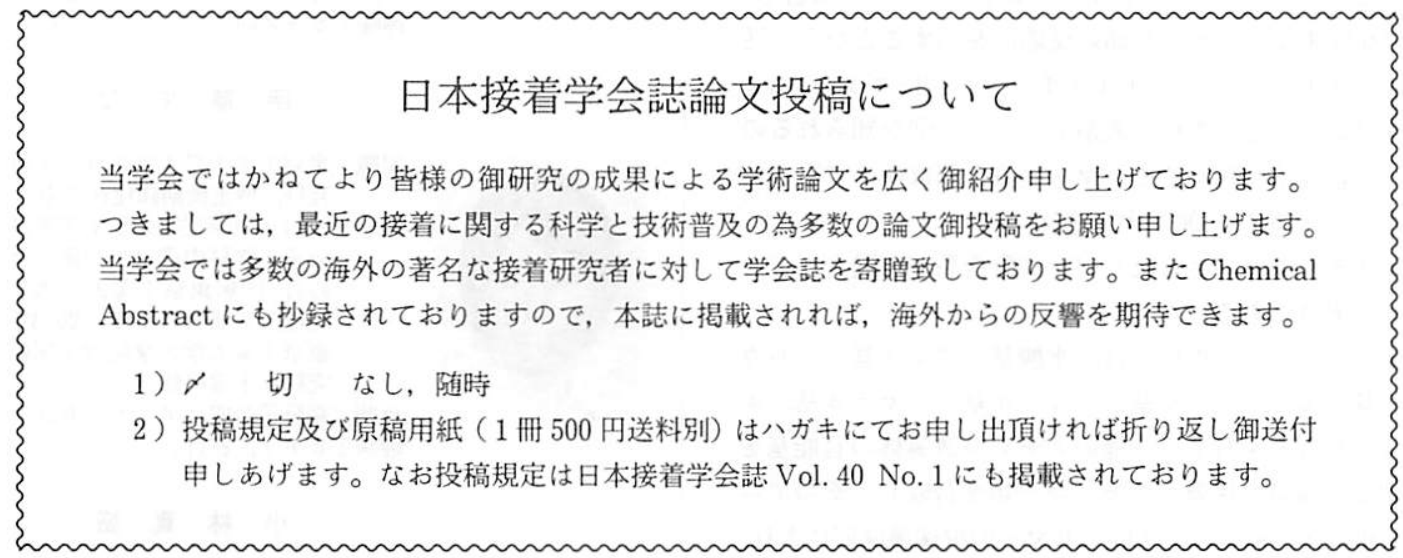

